\title{
Minimization of Environmental Impact of Kraft Pulp Mill Effluents: Current Practices and Future Perspectives towards Sustainability
}

\author{
Gladys Vidal ${ }^{1, * \mathbb{C}}$, Yenifer González ${ }^{1}$, Benjamín Piña ${ }^{2}$, Mayra Jarpa ${ }^{1}$ and Gloria Gómez ${ }^{1}$ \\ 1 Environmental Engineering \& Biotechnology Group (GIBA-UDEC), \\ Environmental Science Faculty \& EULA-CHILE Center, Universidad de Concepción, \\ Concepción 4030000, Chile; yenigonzalez@udec.cl (Y.G.); mayjarpa@gmail.com (M.J.); \\ gloriagomezosorio@gmail.com (G.G.) \\ 2 IDAEA-CSIC, Jordi Girona, 18, 08034 Barcelona, Spain; bpcbmc@cid.csic.es \\ * Correspondence: glvidal@udec.cl
}

check for updates

Citation: Vidal, G.; González, Y.; Piña, B.; Jarpa, M.; Gómez, G. Minimization of Environmental Impact of Kraft Pulp Mill Effluents: Current Practices and Future Perspectives towards Sustainability. Sustainability 2021, 13, 9288. https:// doi.org/10.3390/su13169288

Academic Editor: Mohammadreza Kamali

Received: 1 July 2021

Accepted: 10 August 2021

Published: 18 August 2021

Publisher's Note: MDPI stays neutral with regard to jurisdictional claims in published maps and institutional affiliations.

Copyright: (c) 2021 by the authors. Licensee MDPI, Basel, Switzerland. This article is an open access article distributed under the terms and conditions of the Creative Commons Attribution (CC BY) license (https:/ / creativecommons.org/licenses/by/ $4.0 /)$.

\begin{abstract}
Kraft mill effluents are characterized by their content of suspended solids, organic matter and color due to the presence of lignin, lignin derivatives and tannins. Additionally, Kraft mill effluents contain adsorbable organic halogens and wood extractive compounds (resin acids, fatty acids, phytosterol) and show high conductivity due to the chemical compounds used in the digestion process of pulp. Currently, Kraft mills are operating under the concept of a linear economy and, therefore, their effluents are generating serious toxicity effects, detected in daphnia, fish and biosensors. These effluents are treated by activated sludge and moving bed biofilm systems that are unable to remove recalcitrant organic matter, color and biological activity (toxicity) from effluents. Moreover, under climate change, these environmental effects are being exacerbated and some mills have had to stop their operation when the flows of aquatic ecosystems are lower. The aim of this review is to discuss the treatment of Kraft pulp mill effluents and their impact regarding the current practices and future perspectives towards sustainability under climate change. Kraft pulp mill sustainability involves the closure of water circuits in order to recirculate water and reduce the environmental impact, as well as the implementation of advanced technology for these purposes.
\end{abstract}

Keywords: kraft mill effluents; toxicity; environmental impact; technologies; cycle closure; sustainability

\section{Introduction}

Latin America is leading the installed capacity of Kraft pulp mills, surpassing the installed capacity in North America. The continents that have a greater supply of cellulose fiber are Latin America and the Nordic countries, while the largest demand for cellulose fiber comes from China. The developing countries that install this type of Kraft pulp mill generate processes with the best available technology (BAT) in the market, that is, with continuous pulp digestion systems and elemental chlorine-free (ECF) bleaching pulp. Additionally, developing countries have conventional treatment systems installed and then discharge their effluents to surface ecosystems (i.e., rivers or sea). Developed countries face growing conservationist pressures that limit or make it more difficult to obtain raw materials for industry. Furthermore, in these countries, there are still very competitive locations for the development of plantations; the requirements for forest management certifications and sustainability codes are universal for all countries that produce and export pulp. On the other hand, Europe is no longer the most important regional market, being displaced by China, and pulp based on eucalyptus continues to lead the market growth, adding 3.1 million tons of annual growth.

In this article, for a better understanding of the difficulty that the Kraft pulp mills have in order to implement cycle closure, the origin of the effluent, its generation under BAT, and 
adequate procedures that all industries that export pulp have implemented, as required by international markets, are explained. Due to the raw material and the chemical conditions of the process, it generates a series of environmental impacts that have been evaluated by means of different bioindicators at different trophic levels. The conventional treatment technologies that are currently installed in all Kraft pulp mills are of the conventional, biological type and all discharge their effluents to surface water bodies. However, the water crisis that is affecting many countries that produce Kraft pulp requires sustainability option to increase the level and type of effluent treatment using advanced technology, so as to be able to close certain parts of the production process and, with them, reduce the use of fresh water.

The aim of this review is to discuss the treatment of Kraft pulp mill effluents and their impact regarding the current practices and future perspectives towards sustainability under climate change.

\section{Kraft Mill Process and Effluents}

Wood is known to be the most abundant and renewable source of lignocellulosic material in the world. It has three main components: cellulose (40-45\%), hemicelluloses (20-30\%), and lignin (20-30\%) [1]. Additionally, other organic compounds (2-5\%) can be extracted from digestion processes, including terpenes, polar phenols, fatty acids, resin acid, and sterols. These are known as resins, extractive compounds, or wood extractives [2].

Long fiber wood, such as pine (i.e., Pinus radiata), presents a greater quantity of wood extractives (0.5-7.0\%), while short fiber wood (eucalyptus, i.e., Eucaliptus globulus, Eucaliptus nintens) present a lower quantity (0.2-3.5\%) [3]. Long fiber wood is rich in resin acid [4], while sterols are abundant in short fiber wood [5]. However, the effluents of both long and short fiber woods contain sterols, resin acid, long chain fatty acids, and other compounds. Processes that use short fiber or mixed fiber wood produce a greater extractive compound load in their effluents $[4,5]$. On the other hand, studies have demonstrated that compounds with log Kow (octanol-water partition coefficient) values higher than 4 have accumulation properties and, because of this, probably biological activity. Specifically, Kraft pulp mill effluents generate micropollutants with high Kow, as is the case of stigmasterol (10.2), $\beta$-sitosterol (9.6), abietic acid (4.6-7.5), and dehydroabietic acid (5.7-7.2), among others [6].

On the other hand, the production process of Kraft pulp mills generates different effluents whose physicochemical characteristics depend on the raw material, technology, and processes used. The processes that generate most of the pollutant effluent are digestion and bleaching. Due to this, the best available technologies are installed to increase properties in the pulp and to reduce the absorbable organic halogen (AOX) concentration in the effluent, due to the bleaching process.

Figure 1 summarizes the main compounds that are produced during the main stages of the process of obtaining Kraft cellulose [7].

The main strategies for minimizing effluent generation and its effect are: (a) increased delignification efficiency in earlier stages, which represents a longer bleaching stage, and (b) improved technical conditions for pulp bleaching. The following procedures have been proposed: (1) substituting chloride for another oxidating agent, such as oxygen or chloride dioxide [8,9], (2) water recycling, (3) modifying the washing system [10], and (4) performing the bleaching stage with pulp of greater consistency in order to save water.

All the technological improvements mentioned above will help to improve biodegradation in the effluents, reducing their environmental impact due the biological activity of micropollutants, among others. However, the micropollutants in the generated effluents need to be studied. For example, bleaching technology that does not use chlorates as oxidants (total chlorine-free (TCF)) generates effluents with a smaller contamination load than the effluents produced by elemental chlorine-free (ECF) bleaching processes [11] due to the organic compounds and the highly oxidized compounds present in these effluents [12]. However, the TCF process effluents require chelants such as ethylenediaminetetraacetic 
acid (EDTA) and diethylenetriaminepentaacetic acid (DTPA) which show low biodegradation in treatment plants and, consequently, high incidence in the environment $[13,14]$.

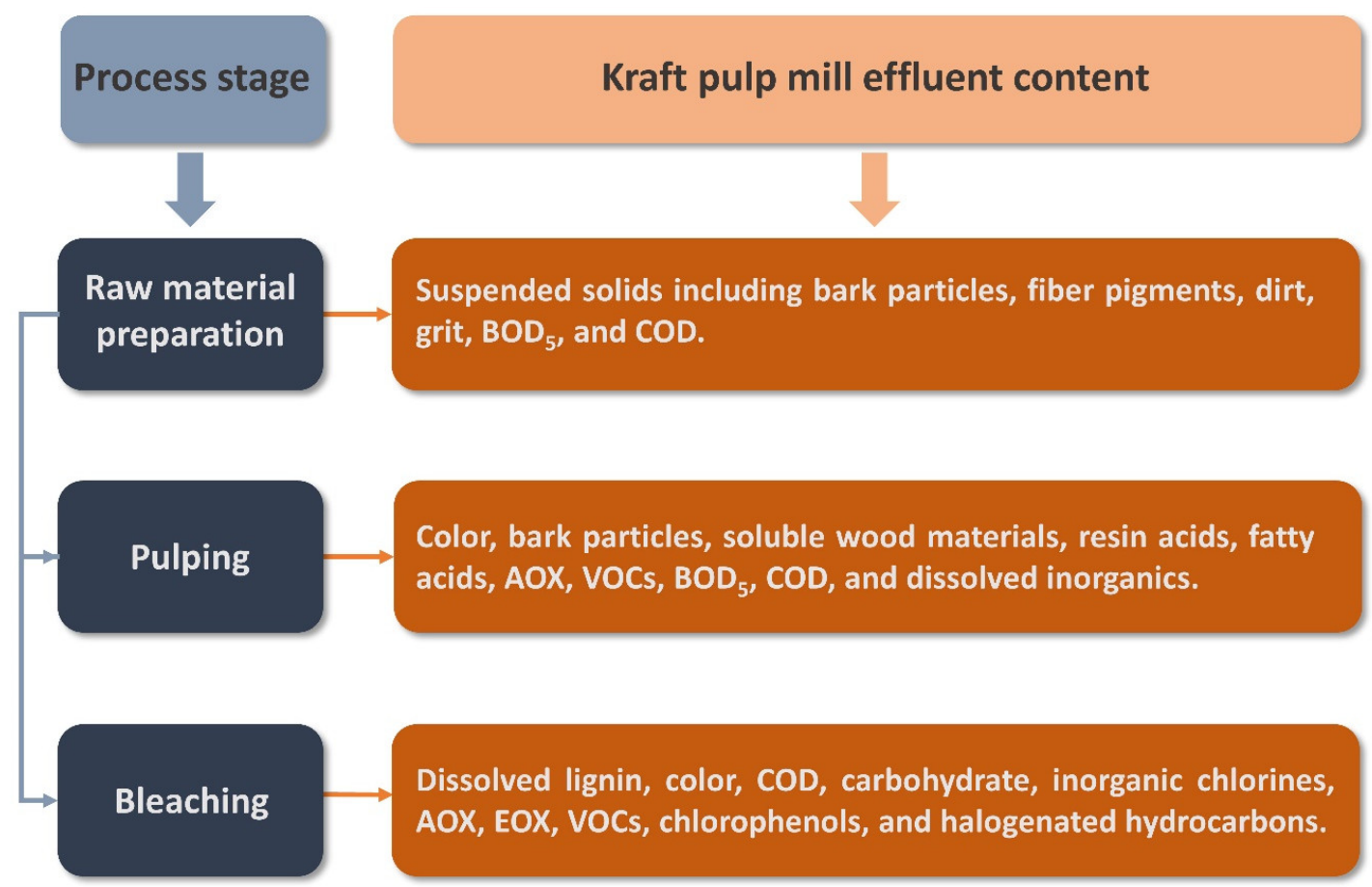

Figure 1. Major pollutants released from Kraft pulp mill effluent. Source: adapted from Kamali and Khodaparast [7]. BOD : $^{2}$ biological oxygen demand; COD: chemical oxygen demand; AOX: adsorbable organic halogens; VOC: volatile organic compounds; EOX: extractable organic halogens.

\section{Recalcitrant Organic Compounds in Kraft Pulp Mill Effluents}

Kraft pulp mill effluents contain a variety of recalcitrant compounds, such as lignosulfonic acid, chlorinated resin acids, chlorinated phenols, dioxins, and chlorinated hydrocarbons. Figure 2 shows a type of classification of organic matter and the possible compound removal by physicochemical, chemical, and biological technology.

Although in most cases the toxicity is low, pulp bleaching effluents are characterized by a high concentration of chemical oxygen demand (COD) (1000 to $7000 \mathrm{mg} / \mathrm{L})$, a low biodegradability ratio (biological oxygen demand, $\mathrm{BOD}_{5} / \mathrm{COD}$ ) of 0.02 to 0.07 , and a moderate concentration of suspended solids ( 500 to $2000 \mathrm{mg} / \mathrm{L}$ ). Compounds, especially those containing chlorine (measured by the parameter AOX) are recalcitrant because they contain chemical structures that are rare in nature, such as the carbon-chlorine bond. It has been widely reported that high molecular weight organic matter (HMW $>1 \mathrm{kDa}$ ) in bleaching effluents is more recalcitrant to biological treatment than low molecular weight organic matter $(\mathrm{LMW}<1 \mathrm{kDa})[15,16]$. Dissolved lignin and its degradation products, hemicelluloses, resin acids, fatty acids, diterpenic alcohols, juveniles, tannins, and phenols are responsible for the dark color and toxicity of the effluent [17].

Lignin and its derivatives are recalcitrant and highly toxic compounds responsible for the high $\mathrm{BOD}_{5}$ and $\mathrm{COD}$ values of the effluents, as well as the dark brown color of the pulp effluents formed during pulping. Lignin is one of the most difficult substances to break down [18]. For example, lignosulfonates have been found to inhibit various biological systems, such as enzyme, toxin and antibiotic functions, and the chlorinated derivatives of lignin are poorly degraded by conventional wastewater treatment processes. During the biological and chemical degradation of chlorinated lignin, small ( $\mathrm{MW}<1 \mathrm{kDa}$ ) harmful compounds can be formed, such as chloroanisoles and chloroveratrols, which, when accumulated in fish, can cause a bad taste. In addition, the concern is that chlorinated lignins release toxic or bioaccumulative compounds or are transformed into biologically 
active compounds [19]. Table 1 shows the physical-chemical characterization of some wood extractives present in effluents from the Kraft pulp industry.

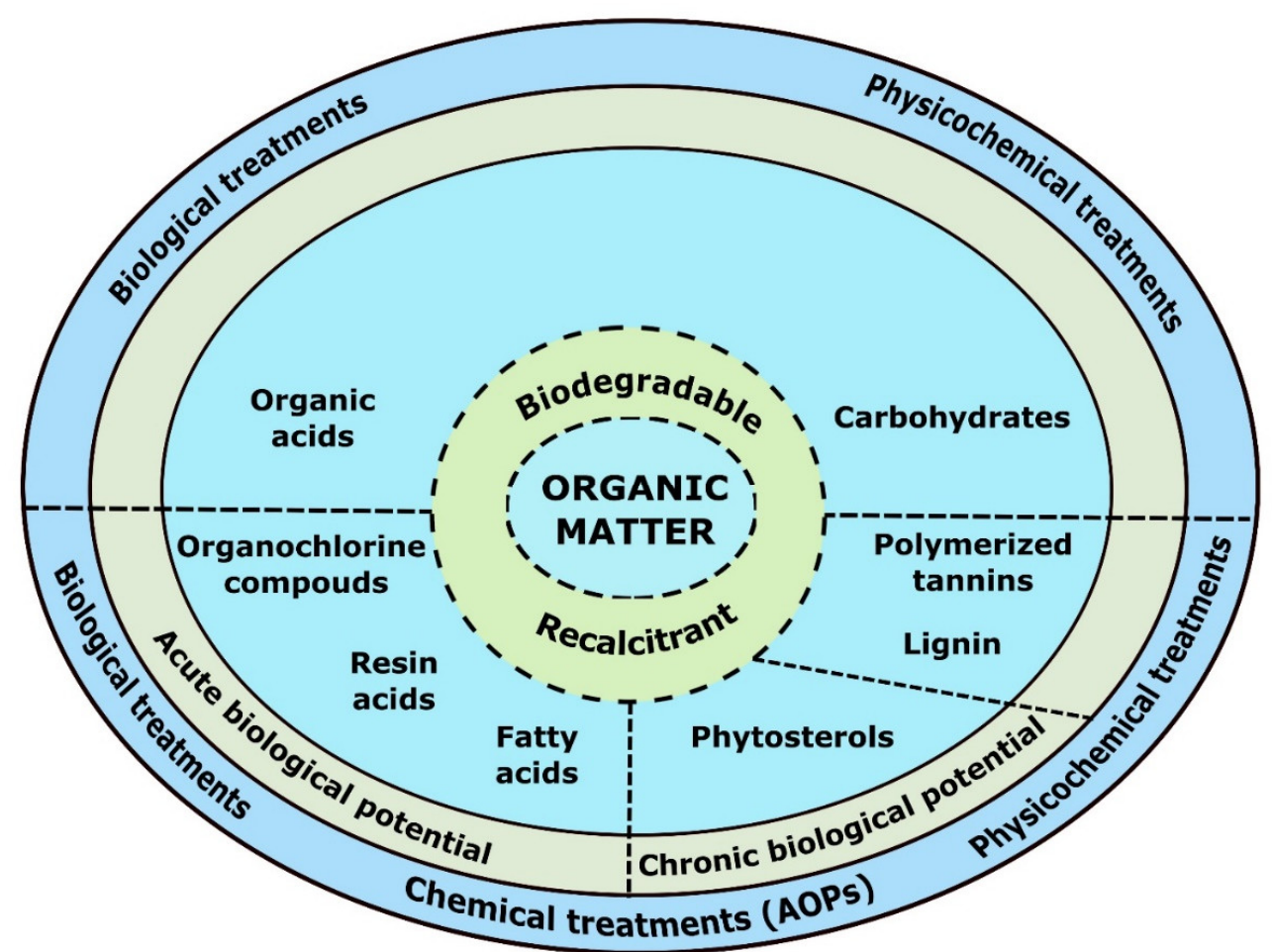

Figure 2. Schematic representation of the biodegradability and recalcitrance of the organic matter contained in Kraft mill effluent and its treatment feasibility using different technologies.

Table 1. Physicochemical properties of some wood extractives with biological activity contained in the Kraft pulp mill effluents.

\begin{tabular}{|c|c|c|c|c|c|}
\hline Compound & Structure & Molecular Weight (g/mol) & Solubility $(\mathrm{mg} / \mathrm{L}) 20^{\circ} \mathrm{C}$ & Log Kow & Reference \\
\hline Abietic acid & & 302.46 & $4.75 \mathrm{mg} / \mathrm{L}$ & $4.6-7.15$ & {$[20]$} \\
\hline Dehydroabietic acid & & 300.44 & $5.1 \mathrm{mg} / \mathrm{L}$ & $5.7-7.25$ & [20-22] \\
\hline Campesterol & & 400.69 & $<0.0001$ & n.r. & {$[23,24]$} \\
\hline Stigmasterol & & 412.70 & $<0.0001$ & 10.20 & [23-25] \\
\hline$\beta$-sitosterol & & 414.72 & $<0.0001$ & 9.65 & {$[23,24,26]$} \\
\hline Genistein & & 270.241 & n.r. & 5.9 & {$[27,28]$} \\
\hline
\end{tabular}




\section{Evaluation of Biological Activity Effects of the Kraft Mill Effluents in the Environment}

The compounds present in Kraft mill effluent discharges in the environment that can potentially interrupt the normal functioning of endocrine systems of the biota in an ecosystem have motivated numerous investigations because the effects on human beings are not yet evident [29]. The traditional method of evaluating these compounds in industrial effluents is by using chemical methods, such as spectrometry (UV-visible, IR) and chromatography (thin layer chromatography (TLC), high-performance liquid chromatography (HPLC)), and gas chromatography-mass spectrometry (CG-MS), which are analytical techniques of great detection power for chemical compound quantification and identification, but their operation is very complex and expensive [30]. On the other hand, potential biological effects of Kraft mill effluents have been studied in experimental exposure experiments in fish $[29,31]$ or Daphnia magna $[6,32,33]$. Specifically in this case, the research group has detected estrogenic activity of Kraft mill treated effluent by a recombinant Saccharomyces cerevisiae yeast. The results indicate that the estrogenic activity values were relatively low, between 1.475 and $0.383 \mathrm{ng} / \mathrm{L}$ of estrogenic equivalent of 17 a-ethynylestradiol (EE2 eq.), where the highest value corresponds to the Eucaliptus globulus effluent and the lowest value to the Pinus radiata effluent $[30,34]$. However, previous works have found toxic effects in treated Kraft mill effluents due to dioxin-like compounds; in other words, ligands of the aryl hydrocarbon receptor (AhR) constitute a significant fraction of the biological activity of Kraft mill effluents [35]. Ectopic activation of AhR constitutes the initial step of the metabolic chain, leading to toxic effects of a variety of different harmful pollutants, such as 2,3,7,8-tetrachlorodibenzo-(p)-dioxin (TCDD) and benzo[a]pyrene (BaP). Immune dysfunction, endocrine disruption, reproductive toxicity, developmental defects, and cancer in vertebrates are some of these effects [36]. Therefore, assays to detect AhR activation and subsequent signal transduction are becoming an extremely useful approach to monitor pollution loads in environmental samples. The advantage in using this biosensor is that yeast is easy to grow and detects chemical compounds rapidly and at a low cost. The application of this test in the field of wastewater treatment is in full expansion. To date, it has been used widely in the evaluation of wastewater treatment plants $[3,30,37]$.

Depending on the effects that these tests need to detect, organisms, cells, and/or tissues can be used. The simplest and best known are the acute toxicity tests that have been developed and standardized by US agencies such as the United States Environmental Protection Agency (USEPA). These toxicity tests can be used to determine a contaminant's capacity (whether a pure substance or effluent) to produce toxic effects in live organisms when they are exposed for a certain time at certain concentrations. The most used organisms in aquatic biotests are daphnia, mainly due to their wide distribution (cosmopolitan), their ecological importance, their sensitivity to disrupted environments, and their short life cycle. As a result, they are considered indicator species for adverse environmental conditions [38]. The adequate survival, growth, and reproduction of daphnia are crucial for success in the environment. Moreover, studies on this species could give information on the effluent quality in terms of the ecosystem trophic chain [39]. Some studies have focused on evaluating the effects of endocrine-disrupting chemicals on daphnia. Thus, Xavier et al. [32] found that Kraft mill effluents induce sexual maturation in female daphnia. The development of secondary sex characteristics has been demonstrated to be altered by endocrine-disrupting chemicals. On the other hand, Olmstead and Le Blanc [40] observed that diethylstilbestrol stimulates the development of the secondary abdominal process in female daphnia. Moreover, studies showed that the effluent factors capable of modifying the body proportions of daphnia have the same effect in pine and eucalyptus. Additionally, they found that micropollutants like $\beta$-sitosterol and stigmasterol contribute to the allometric growth rate (determined as \% of the growth rate of the body length and body width). The phytosterols per se are responsible for 12.9 and $8.1 \%$ of the deviation from the natural shape, while the Kraft mill effluents account for 25.6 to $27.8 \%$ of shape deviation. They concluded that the estrogenic activity of Kraft mill effluents is dependent 
on the species processed for wood pulp, but the effluent treatment and the operation strategy were not evaluated in this work.

A second biological response widely found in fish exposed to bleached Kraft mill effluents is increased detoxification activity in the liver and other tissues [41-43]. The most widely used marker for this biological activity is the activation of cytochrome P450 1A (cyp1a), monitored through the associated enzymatic activity of ethoxyresorufin Odeethylase (EROD) $[44,45]$ or analyzing changes in the transcription of the cypla gene using real-time polymerase chain reaction techniques [46-48]. This activity, also called "activity similar to dioxins", is not considered an adverse outcome as such, although it constitutes the initial step in the metabolic chain leading to the toxic effects of a variety of harmful contaminants, such as 2,3,7,8-tetrachlorodibenzo-(p)-dioxin (TCDD), coplanar PCBs, and benzopyrenes, among others [36]. It is important to emphasize that this response is mediated by the interaction of contaminants with a specific nuclear receptor, the aryl hydrocarbon receptor (AhR), also known as the "dioxin receptor", with which mice lacking the corresponding gene become resistant to the tumorigenic effects of dioxins or benzopyrenes $[49,50]$.

Table 2 summarizes some effects on the biological activity of some species exposed to effluents or compounds from Kraft pulp mills. Additionally, the means of detection are indicated.

Table 2. Effects on the biological activity of some species exposed to effluents or compounds from Kraft pulp mills.

\begin{tabular}{|c|c|c|c|c|}
\hline Exposed Species & Effluent/Compound & Toxicity Effect & Detection & Reference \\
\hline Gambusia affinis & BKME & Gonopod formation (female) & Body measurements & [51] \\
\hline Oryzias latipes & Genistein $(1000 \mu \mathrm{g} / \mathrm{L})$ & $\begin{array}{l}\text { Intersex at } 12 \% \text {. Large ovarian lumen } \\
\text { Higher level of VTG and EROD in }\end{array}$ & Histological analysis & [27] \\
\hline $\begin{array}{l}\text { Trichomycterus areolatus } \\
\text { and Percilia irwini }\end{array}$ & $\begin{array}{c}\text { Bío-Bío river: downstream and } \\
\text { upstream pulp mill effluent } \\
\text { discharges }\end{array}$ & $\begin{array}{l}\text { fish exposed to downstream pulp } \\
\text { mill effluent discharges. } \\
\text { Additionally, gonad alterations and } \\
\text { intersex juvenile fish }\end{array}$ & $\begin{array}{l}\text { Western blot, Northern } \\
\text { blot. VTG, EROD, LSI, } \\
\text { GSI, GC-MS, ELISA }\end{array}$ & [29] \\
\hline Coregonus lavaretus & BKME-ECF (5 mg/fish) & Induction of VTG mRNA & Northern blot & [52] \\
\hline Daphnia magna & BKME $(6.25,12.5,25,50,100 \%)$ & Abdominal growth & $\begin{array}{l}\text { Toxicity tests, CG-MS, } \\
\text { microscopy }\end{array}$ & [32] \\
\hline Carassius carassius & $\beta$-sitosterol (200 mg/g) & Reduction in the size of the gonads & $\begin{array}{l}\text { VTG, GSI, HSI and } \\
\text { histological analysis }\end{array}$ & {$[53]$} \\
\hline Danio rerio & DHAA $(50 \mu \mathrm{g} / \mathrm{L})(\mathrm{F} 0 \mathrm{y}$ F1) & $\begin{array}{c}\text { VTG increase (F1 males); low VTG } \\
\text { levels (F0 males) }\end{array}$ & $\begin{array}{l}\text { VTG, ELISA, and } \\
\text { histological analysis }\end{array}$ & [54] \\
\hline Sprague Dawley rats & $\begin{array}{c}\text { Genistein }(12.5,25,50, \\
100 \mathrm{mg} / \mathrm{kg})\end{array}$ & $\begin{array}{l}\text { VTG increase (F1 males); low VTG } \\
\text { levels (F0 males) } \\
\text { Females: irregularities in the heat } \\
\text { cycle, histopathological changes in } \\
\text { the ovaries and uterus, loss of } \\
\text { fertility }(100 \mathrm{mg} / \mathrm{kg})\end{array}$ & Histological analysis & [55] \\
\hline $\begin{array}{l}\text { Selenastrum capricornutum, } \\
\text { Lemna aequinoctialis }\end{array}$ & BKME-ECF & 7-day growth & 7-day growth & {$[56]$} \\
\hline
\end{tabular}

VTG: vitellogenin; EROD: ethoxyresorufin-o-deethylase; ELISA: enzyme-linked immunosorbent assay; BKME: bleaching kraft mill effluent; ECF: elementary chlorine free; GC-MS: gas chromatography-mass spectrometry; GSI: geological strength index; HSI: heat stress index; DHAA: dehydroabietic acid. Adapted from Monsálvez et al. [28].

Table 2 shows the toxicity of the effluents from the Kraft pulp industry. Many studies have found toxicity in the effluents that are discharged to surface bodies. This means that there are bioactive compounds that are not eliminated by the conventional secondary treatments that are currently installed in the production processes. Table 1 shows examples of extractive compounds of difficult biodegradability that may be present in effluent discharges (i.e., campesterol, stigmasterol, $\beta$-sitosterol, genistein). All these compounds share basic phenolic structures that are difficult to biodegrade, joined by double bonds.

In addition, biological potential studies on these effluents have used the recombinant Saccharomyces cerevisiae biosensor (yeast estrogen assay, YES). Therefore, if this strain is genetically modified with the human estrogen receptor (hER), a recombinant yeast assay (ER-RYA) bioindicator can be obtained and if YES is genetically modified with the human aryl hydrocarbon receptor (AhR), it is possible to detect compounds with structures similar to dioxins and furans (YCM-RYA) [30]. Chamorro et al. [57] studied three Kraft mill effluents with different raw materials (P. radiata, E. globulus, and their mixture: mixed), 
detecting estrogenic activity expressed as 17- $\alpha$-ethinylestradiol equivalent (EE2 eq.) of $0.383 \mathrm{ng}$ EE2 Eq/L, $1.475 \mathrm{ng}$ EE2 Eq/L, and 0.849 ng EE2 Eq/L, for effluents of P. radiata, E. globulus, and mixed, respectively, Fernández et al. [58] obtained values of 42-83 ng EE2 Eq/L. In the case of ER-RYA (estrogenic activity) and YCM-RYA ("dioxin-like" activity) studies, carried out by Monsálvez et al. [28], estrogenic activity values expressed as 17- $\beta$ estradiol (E2 eq.) were from 0.19-0.68 ng E2 Eq/L and 0.28-0.67 ng E2 Eq/L for effluents of P. radiata and E. globulus, respectively, and for dioxin-like activity, values of $21.35 \mathrm{ng}$ E2 $\mathrm{Eq} / \mathrm{L}$ and $753.80 \mathrm{ng}$ E2/L were found for effluents of P. radiata and E. globulus, respectively, while Chamorro et al. [30], in sediment samples near Kraft cellulose discharges, detected low levels of responses for YES and RYA.

In addition to this, the effects of aquatic toxicity generated by Kraft mill effluent discharges may produce a direct or indirect influence on the food chain related to productive activities, such as agriculture and fishing. Moreover, toxic compound discharges are unsuitable for the growth and development of microbes, plankton, and small fish. This further affects the growth of larger fish. Furthermore, the accumulation of toxic materials, such as polyhydroxybutyrates and persistent organic pollutants, makes them toxic to secondary and tertiary consumers, causing health problems.

\section{Kraft Pulp Mill Effluents Treated by Conventional Technologies}

The biological aerobic treatments with suspended biomass most commonly used in Kraft mills are: aerated lagoons, activated sludge (AS) [59], and moving bed biofilm reactors (MBBRs) [60,61].

Aerated lagoons are easy to operate but require a long hydraulic retention time (HRT) and elevated land extensions. Additionally, aerated lagoons have problems in separating the generated excess of solids. Furthermore, the operating conditions strongly influence the degradation of aromatic compounds [62]. Xavier et al. [59] demonstrated that in anoxic areas, intermediate compounds of resin acid biodegradation (e.g., retene) can produce disruption activity. However, in optimal operating conditions, the biodegradation of these compounds can be greater than 90\% [22]. Aerobic treatment of Kraft mill effluents by aerated lagoon systems reduces COD from $35-50 \%$, BOD $_{5}$ up to $90 \%$, and suspended solids $80 \%$ [22,59]. However, organic compounds with high molecular weight and recalcitrant compounds are partially transformed by aerobic bacteria (biotransformation) without reaching complete mineralization of organic matter to $\mathrm{CO}_{2}$ and $\mathrm{H}_{2} \mathrm{O}$ [62]. However, at an organic load rate $(\mathrm{OLR})$ greater than $2 \mathrm{~g} \mathrm{COD} / \mathrm{L} \cdot \mathrm{d}($ food $/$ microorganisms $(\mathrm{F} / \mathrm{M})=0.56 \mathrm{~g}$ COD $/ g$ VSS.d), phytosterol removal was $66.5 \%$, although there was no removal of either acute toxicity (median lethal concentration, LC50, $48 \mathrm{~h}=88.22 \%$ ) or chronic reproduction and growth toxicity (lowest observed effect concentration, LOEC $=20 \%$ ), whereas genotoxicity increased 16\% [59]. Optimal operation of aerobic treatment systems depends on the adequate control of operational parameters, such as: organic load rate, $\mathrm{pH}$, temperature, and aeration [59-61,63].

On the other hand, activated sludge systems used to aerobically treat Kraft mill effluents at the industrial scale remove $50 \%$ of COD in effluents from softwood processing and more than $65 \%$ of COD in effluents from hardwood processing industries [63]. However, some treatments do not remove the effluent color efficiently, and in other cases they even increase it. Successful removal of extractive compounds (up to 97\%) can be verified in activated sludge, but it is not totally clear if the removal of specific compounds, such as resin acid (43-94\%) and phytosterols (41-99\%), is due to biotransformation or adsorption in the sludge [64]. However, the treatment of eucalyptus effluent removes almost $64 \%$ of the total sterol content in the primary treatment, while $36 \%$ is passed to the activated sludge reactor. Of these contents, between 41 and $67 \%$ were biodegraded or biotransformed in the biological system, and between 31 and 57\% were removed by adsorption in the sludge and then subsequently thickened and disposed of [64]. Mahmood-Khan and Hall [26] observed that $\beta$-sitosterol and $\beta$-sitostanol are the most removed phytosterols when Kraft cellulose effluents are biologically treated (60-80\%). 
In the effluents coming from processes using eucalyptus as raw material, a higher sterol concentration is found, in which $\beta$-sitosterol presents the highest proportion (up to $34 \mathrm{~g}$ ptp) [34]. The secondary treatments of the nine plants in this study presented an elevated efficiency in resin acid and sterol degradation. However, the final system's removal efficiency can vary between 53 and $99 \%$. This study also demonstrated that the resin acid and saturated and unsaturated acid concentrations found in the effluent depend on the type of wood used as raw material. From the point of view of the treatment of these compounds, the volatile unsaturated fatty acids present a higher degradation percentage than the saturated fatty acids. Xavier et al. [32], in a comparative study, show that an activated sludge system presents greater elimination efficiency for compounds with estrogenic activity in an aerated lagoon. Similarly, the removal of phytosterols in conventional activated sludge systems operating at an OLR of $9.0 \mathrm{gCOD} / \mathrm{L} \cdot \mathrm{d}$ and HRT of $3 \mathrm{~h}$ was $70.3 \%$. Still, even though the acute and chronic toxicity were completely removed, the genotoxic effect increased 6\%. At low $\mathrm{F} / \mathrm{M}$ ratios, the biomass sedimentation in activated sludge was affected [60].

On the other hand, MBBR systems can operate at an HRT of less than $2 \mathrm{~h}$ and their operation can be extended to nitrogen and phosphorus removal. As a result, an MBBR system can use $1 / 5-1 / 10$ of the space occupied by a conventional sludge system [60]. The biofilm used in this type of system plays an essential role in the system efficiency. The transfer of oxygen and/or nutrients can be a limiting factor for biofilm growth and for system robustness. Numerous studies have been performed in which the best operational conditions are evaluated for systems using this type of technology, depending on the substrate used, and there have been studies that evaluate the support together with the operating conditions [63]. Specifically, AnoxKaldnes studied the behavior of a biofilm that grows on a support for systems that operate in the first stage of the biological treatment system (higher $\mathrm{BOD}_{5}$ load), and hybrid systems or systems that use it as a polishing stage $[60,61]$. Table 3 shows the removal performance of conventional technologies for organic matter and active compounds contained in the Kraft pulp mill effluents.

Table 3. Performance of the organic matter and active compounds contained in the Kraft pulp mill effluents treated by conventional technologies.

\begin{tabular}{|c|c|c|c|c|c|c|}
\hline Technology & $\begin{array}{l}\text { HRT } \\
\text { (h) }\end{array}$ & $\begin{array}{c}\text { OLR } \\
\left(\mathrm{kgBOD}_{5} / \mathrm{m}^{3} \cdot \mathrm{d}\right)\end{array}$ & $\begin{array}{c}\mathrm{BOD}_{5} \\
(\%)\end{array}$ & $\begin{array}{c}\text { COD } \\
(\%)\end{array}$ & $\begin{array}{c}\text { Resin Acid } \\
(\%)\end{array}$ & $\begin{array}{c}\text { Phytoesterols } \\
(\%)\end{array}$ \\
\hline Aerated lagoon & $480-48$ & $0.01-0.2$ & $85-96$ & $42-55$ & $50-97$ & $61-78$ \\
\hline Activated sludge & $48-4.5$ & $0.4-1.4$ & $85-99$ & $42-93$ & $80-99$ & $50-98$ \\
\hline MBBR & $1.7-3$ & $0.3-10$ & 75-99 & $60-90$ & $85-99$ & 98-99 \\
\hline
\end{tabular}

MBBR: moving bed biofilm reactor; HRT: hydraulic retention time; OLR: organic load rate; $\mathrm{BOD}_{5}$ : biological oxygen demand; COD: chemical oxygen demand; AOX: adsorbable organic halogens [3,22,57,59-61].

\section{Advanced Treatments Used in Kraft Pulp Mill Effluent Treatments}

Advanced oxidation processes (AOPs) and membrane technologies have emerged as an alternative to conventional technologies for the oxidation of recalcitrant compounds. These processes are based on the generation of hydroxyl radicals, which are strong oxidants for the complete mineralization of the target compounds.

Table 4 summarizes studies carried out both in physical and physical-chemical treatment systems, such as chemical precipitation and chemical treatments, such as AOPs, all of them compared regarding COD, TOC, and AOX removal in Kraft mill effluents. Thus, for chemical precipitation, the removal of COD is $63-77 \%$, while for TOC it is $30-70 \%$, with very few studies regarding active compounds, such as phytosterols, with a removal greater than $90 \%$ for $\beta$-sitosterol and stigmastanol [65]. In the case of AOPs, the COD and TOC removal range from $20-94 \%$ and $8-96 \%$, respectively [66]. In addition to this, the removal efficiencies of resinic acids, linoleic acid, and $\beta$-sitosterol were $36-93 \%, 84 \%$, and $87 \%$, respectively, by the technologies of $\mathrm{UV} / \mathrm{H}_{2} \mathrm{O}_{2} / \mathrm{Fe}^{+2}$ and $\mathrm{O}_{3}[65]$. 
Table 4. Efficiencies in different physicochemical and chemical treatment technologies used with Kraft pulp mill effluents.

\begin{tabular}{|c|c|c|c|c|c|c|}
\hline Technology & $\begin{array}{c}\text { COD } \\
(\%)\end{array}$ & $\begin{array}{c}\text { TOC } \\
(\%)\end{array}$ & $\begin{array}{c}\text { Color } \\
(\%)\end{array}$ & $\begin{array}{l}\text { Phenolic } \\
\text { Compounds } \\
(\%)\end{array}$ & $\begin{array}{c}\text { Active } \\
\text { Compounds } \\
(\%)\end{array}$ & Reference \\
\hline \multicolumn{7}{|c|}{ Physicochemical technology } \\
\hline Chemical precipitation & $63-77$ & $30-70$ & 96 & n.r. & $>90^{a, b}$ & {$[65,67,68]$} \\
\hline \multicolumn{7}{|c|}{ Chemical technology } \\
\hline $\mathrm{UV} / \mathrm{H}_{2} \mathrm{O}_{2}$ & 74 & $8-45$ & 41 & $24-91$ & n.r. & {$[69,70]$} \\
\hline $\mathrm{H}_{2} \mathrm{O}_{2} / \mathrm{Fe}^{+2}$ & $>60$ & $20-90$ & 85 & $32-100$ & n.r. & {$[69,71]$} \\
\hline $\mathrm{UV} / \mathrm{H}_{2} \mathrm{O}_{2} / \mathrm{Fe}^{+2}$ & n.r. & $60-96$ & 82 & n.r. & $93^{\mathrm{a}}, 84^{\mathrm{c}}, 97^{\mathrm{d}}$ & {$[65,69,71]$} \\
\hline $\mathrm{O}_{3}$ & $29-76$ & $19-51$ & $81-97$ & $85-100$ & $36-90^{\mathrm{c}}$ & {$[33,72,73]$} \\
\hline $\mathrm{O}_{3} / \mathrm{H}_{2} \mathrm{O}_{2}$ & 31 & n.r. & 81 & $58-93$ & n.r. & {$[69,74]$} \\
\hline $\mathrm{O}_{3} / \mathrm{UV}$ & 20 & n.r. & 30 & $81-93$ & n.r. & {$[70,75]$} \\
\hline UV/Zn & $69-94$ & 80 & n.r. & n.r. & n.r. & [76] \\
\hline $\mathrm{UV} / \mathrm{TiO}_{2}$ & $75-80$ & n.r. & n.r. & $42-78$ & n.r. & {$[70,77]$} \\
\hline $\mathrm{O}_{3} / \mathrm{UV} / \mathrm{ZnO} ; \mathrm{O}_{2} / \mathrm{UV} / \mathrm{Zn}$ & 50 & n.r. & 40 & n.r. & n.r. & [75] \\
\hline \multicolumn{7}{|c|}{ Physical technology } \\
\hline Reverse osmosis & & & 100 & & & [78] \\
\hline Ultrafiltration & n.r. & n.r. & 92 & n.r. & $72 \mathrm{e}$ & [79] \\
\hline Nanofiltration & n.r. & n.r. & 72 & n.r. & $82^{e}, 100^{f}$ & {$[79,80]$} \\
\hline
\end{tabular}

n.r: not registered; a: $\beta$-sitosterol; b: stigmastanol; c: resinic acids; d: linoleic acid; e: AOX: adsorbable organic halogens; f: endocrinedisrupting activity. COD: chemical organic demand; TOC: total organic carbon.

On the other hand, ozonation as a unit treatment has proven to be a strong disinfectant and capable of eliminating color and oxidizing recalcitrant compounds without altering the toxicity of the treated effluent, due to the total mineralization of the compounds $[65,81]$. Mainardis et al. [82] showed that ozone treatment could effectively replace tertiary physicochemical treatment in terms of COD and TSS elimination, which would mean an economic saving of EUR 300,000/year and the investment could be recovered in approximately 7 years.

Furthermore, within the AOPs are photoelectrocatalysis (PEC) processes, which arise from the combination of photocatalysis (PC) and electrochemical (CE) processes. This technology has been evaluated little for Kraft mill effluents, while it is sustainable because it can compensate for the high electrical energy consumption of the EC processes and the input of external current in the PEC systems. In these systems, $\mathrm{TiO}_{2}$ is one of the most widely used and most studied photoanode materials due to its non-toxicity, low cost, and strong oxidizing capacity $[17,83]$. Rajput et al. [84] found that $\mathrm{TiO}_{2}$ electrodes together with $\mathrm{Au}$ improve the photoelectrocatalytic activity of $\mathrm{TiO}_{2}$ electrodes, producing a $63.5 \%$ reduction in COD and $44.4 \%$ in TOC.

Systems based on membrane filtration have been shown to have a high removal of color, COD, AOX, salts, heavy metals, and total dissolved solids. These processes can range from microfiltration (MF), ultrafiltration (UF), and nanofiltration (NF) to reverse osmosis (RO) [19]. Through reverse osmosis, it was possible to obtain a maximum removal of $88 \%$ of $\mathrm{BOD}_{5}$ and $89 \%$ of COD [78], with the typical efficiency of membrane technologies being 50 to $90 \%$. On the other hand, regarding organochlorinated compounds, the highest removal of AOX and color achieved by ultrafiltration was 72 and $92 \%$, respectively. Meanwhile, the total removal of color and more than $90 \%$ removal of AOX are achieved by nanofiltration [79]. Moreover, Salvaterra et al. [80] show that nanofiltration is able to prevent endocrine-disrupting activity. The membrane used as a tertiary treatment could contribute to removing organic compounds contained in the bleaching effluents with the possibility to reuse the effluent within the process, thus reducing discharges with active micropollutants to aquatic ecosystems.

\section{Towards a Circular Economy and Sustainability in Kraft Pulp Mills: Perspectives}

The pulp and paper industry has received much criticism from all over the world, particularly from environmentalist groups. Lumber harvesting for the paper industry has been linked to increased deforestation in the world's forests. On the other hand, when a monoculture of pine and/or eucalyptus plantations is introduced, water stress occurs 
in the disrupted hydrographic basins, generating great social conflicts due to pressure on the drinking water sources. This type of industry generates two different types of pressure on the water of an ecosystem. On the one hand, due to the consumption of large amounts of water by metabolism due to the requirements of the plant, the water that is taken underground is evapotranspired by the plants and then the amount of surface water is reduced. On the other hand, the small amount of surface water available is not enough to then dilute the components of the effluents that are discharged from Kraft pulp mill processing.

Under a climate change scenario, water is a scarce resource and an element of social conflict due to the various uses that an ecosystem must provide. Currently, the Kraft pulp industry is working in an open circuit. That is, it takes water from ecosystems, uses it in the technological process and then discharges the treated effluent to surface ecosystems. However, the sustainability of the industry in terms of water resources can be a problem in the short and medium term for two reasons: (a) insufficient water in the ecosystem to feed the production process and (b) insufficient flow for aquatic ecosystems to promote dilution of the effluents to be discharged.

For this reason, it is very important to evaluate quaternary treatment systems that allow a final effluent quality that mean it can be reused while maintaining the stable operation of the process. The recirculation of water, under a closed cycle, in the Kraft pulp industry must include not only the removal of organic compounds by conventional technology, but also ions dissolved (non-process elements) in a concentration such that they do not generate problems, such as incrustations, corrosion, and quality problems in the final product due to their accumulation. Therefore, it is desirable to explore the coupling of various biological, physical, and chemical technologies, thinking about the recovery of water, energy, and valuable or undesirable compounds for these production processes. Figure 3 shows the projection of the operation of a Kraft pulp mill operating in an open circuit to a closed cycle. Currently, this considers the scientific evidence of current impacts on ecosystems. On the other hand, it shows the possibility that these processes can close the cycle, changing to closed-cycle systems due to the introduction of quaternary technologies of a physicochemical type.

Currently, there are no (or not publicly known) bleached Kraft pulp plants that reuse all of their effluents [85]. However, reverse osmosis (RO) is the most versatile desalination method for the treatment of water of any salinity, from brackish water to high-salinity water, linking non-process elements from Kraft pulp mill effluents [86]. The main weaknesses are the fouling of the membranes due to the action of organic substances, which can be solved with an adequate pre-treatment, and the formation of crystals that are embedded in the membranes, which affect their performance and limit the recovery achieved [87]. None of these options have been applied on an industrial scale to treat bleached Kraft pulp mill effluents.

On the other hand, electrodialysis (ED) is an electrochemical separation process which employs electrically charged ion exchange membranes with an electrical potential difference as a driving force. In electrodialysis, ions in solution migrate through ionselective membranes in an electric field [86,87]. The membranes are impervious to water, so, unlike RO, ED is based on promoting selective ion transport rather than selective transport of water. However, the energy consumption is mainly due to the electric field, while in $\mathrm{RO}$, energy is used to pump the water through the membranes. A variation of ED is EDR, in which the polarity of the electrodes is periodically reversed (the hydraulic polarity is also reversed), generating an exchange of the concentrated cells for the diluted cells and vice versa. This technology promotes the separation of particles deposited on the membranes, automatic cleaning of the system, and greater resistance to fouling by organic contaminants or salt scale, compared to RO. This makes it a better option in the face of adverse conditions, such as Kraft mill effluents. Regarding the energy consumption, it is similar to RO, although it depends on the concentration of salts in the solution. 


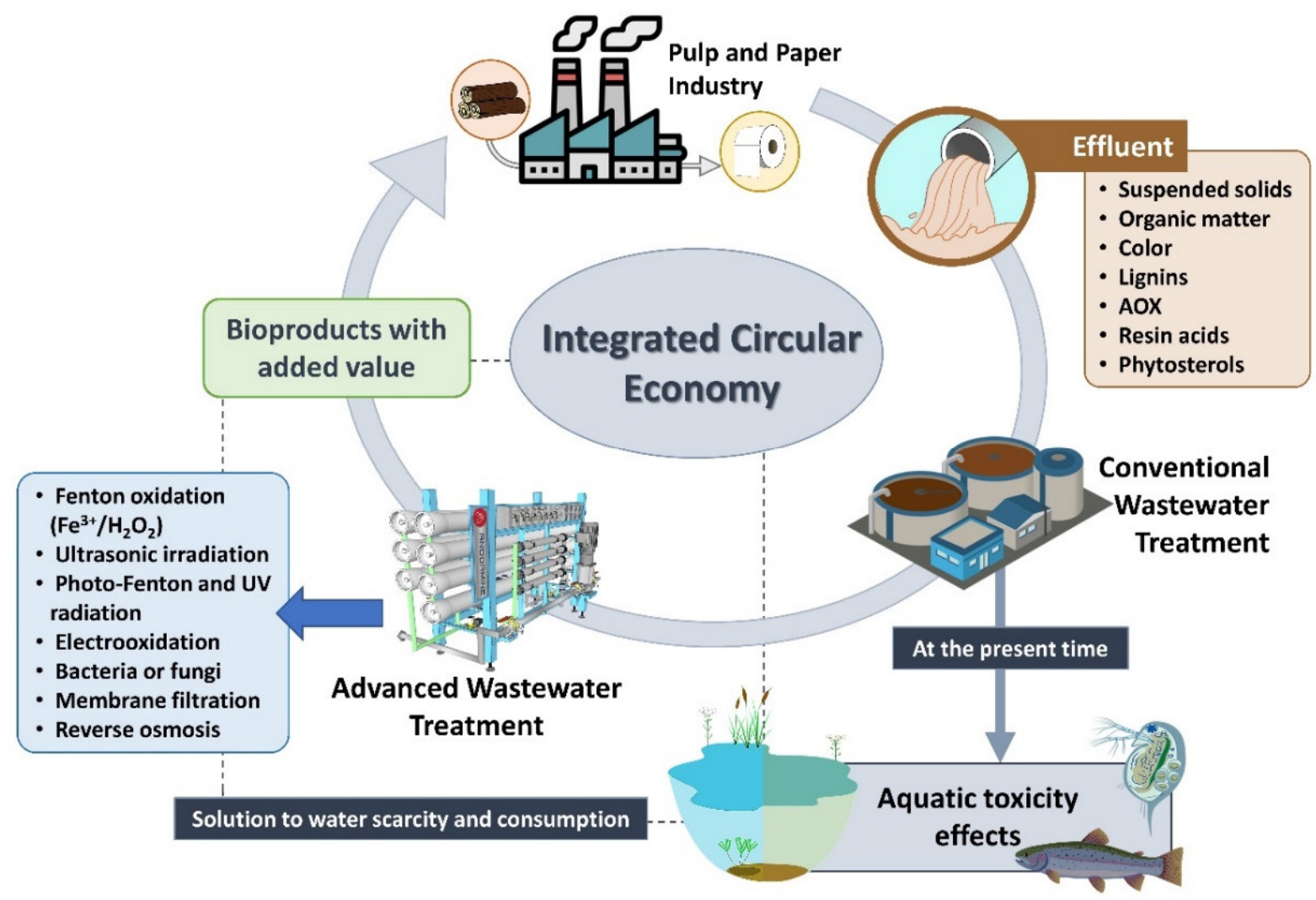

Figure 3. Integrated circular economy in the Kraft pulp mill.

The circular economy will promote the biorefinery of lignocellulosic compounds. In developing countries, where the raw material has low value, the biorefinery of lignocellulosic compounds has not had a decided impact on basic and applied research regarding biorefinery of lignocellulosic compounds. The market has only given space to the main bleached Kraft pulp product. However, under climate change and the new production scenarios of water scarcity, the research of the current biorefinery concepts should be elaborated and optimized for the integrated utilization of all products in high-value applications rather than focusing on bioethanol, biofuels, or sugars only, as is still common to date [88]. In particular, the engineering of lignin is not studied. Nevertheless, considering the crucial role of lignin and other biomass components, the development of the different biotechnologies of biomass and lignin, in particular, are very promising research fields, in light of the multiple future applications, such as fibers, nanofibers, nanoparticles, and products, among many others not yet known. In addition to that, parallel development of the biotechnological potential of plant-associated microorganisms will be carried out [89].

These include technical issues associated with integrating operation units with each other, integrating production of individual products into a multi-product biorefinery, and integrating biorefineries into the broader resource, economic, and environmental systems in which they function. We anticipate that coproduction of multiple products, for example, production of fuels, chemicals, power, and/or feed, is likely to be essential for economic viability. Lifecycle analysis is necessary to verify the sustainability and environmental quality benefits of a particular biocommodity product or process. We see biocommodity engineering as a legitimate focus for graduate study, which is responsive to an established personnel demand in an industry that is expected to grow in the future. Graduate study in biocommodity engineering is supported by a distinctive blend of intellectual elements, including biotechnology, process engineering, and resource and environmental systems [90]. 


\section{Conclusions}

The consequences of climate change and water scarcity are forcing Kraft pulp companies to investigate alternatives to managing water, moving from an open cycle to a closed cycle. Due to the chemical characteristics of these effluents and as the currently installed technology generates final effluents with a fraction of recalcitrant organic matter, it is important to investigate technology that is coupled to the currently installed biological technologies. The separation of some effluents at the source, as well as the intensification of the treatment of the final effluent of the Kraft mill, promotes the idea of coupling more advanced membrane-type technologies (i.e., reverse osmosis or electrodialysis) and/or chemical technology (i.e., advanced oxidation processes) which may be the key to generating perspectives of sustainability of the Kraft pulp mills that are operating in countries strongly affected by climate change.

The coupling of technology to make the Kraft pulp mill processes sustainable will cause a closing of the cycle, enhancing the value of the raw material and giving space to the integration of the operation units with each other, integrating production of individual products into a multi-product biorefinery. This productive change will generate incentives for the development of biotechnology of lignocellulosic compounds in general, promoting an integration between natural resources, economy, and the environment.

Author Contributions: Conceptualization, G.V. and B.P.; methodology, M.J.; software, G.G.; validation, M.J.; formal analysis, M.J.; investigation, M.J.; resources, G.V.; data curation, G.G.; writingoriginal draft preparation, B.P., G.G., Y.G., and G.V.; writing—review and editing, G.G. and G.V.; visualization, G.G.; supervision, G.V.; project administration, G.V.; funding acquisition, G.V. All authors have read and agreed to the published version of the manuscript.

Funding: This research was funded by ANID/FONDAP/15130015.

Acknowledgments: This work was supported by ANID/FONDAP/15130015.

Conflicts of Interest: The authors declare no conflict of interest.

\section{References}

1. Krogell, J.; Korotkova, E.; Eränen, K.; Pranovich, A.; Salmi, T.; Murzin, D.; Willför, S. Intensification of hemicellulose hot-water extraction from spruce wood in a batch extractor-Effects of wood particle size. Bioresour. Technol. 2013, 143, 212-220. [CrossRef]

2. Adamová, T.; Hradecký, J.; Pánek, M. Volatile organic compounds (VOCs) from wood and wood-based panels: Methods for evaluation, potential health risks, and mitigation. Polymers 2020, 12, 2289. [CrossRef]

3. Chamorro, S.; Monsalvez, E.; Hernández, V.; Becerra, J; Mondaca, M.A.; Piña, B.; Vidal, G. Detection of estrogenic activity from kraft mill effluents by yeast estrogen screen. Bull. Environ. Cont. Toxicol. 2010, 84, 165-169. [CrossRef] [PubMed]

4. Baroutian, S.; Robinson, M.; Smit, A.M.; Wijeyekoon, S.; Gapes, D. Transformation and removal of wood extractives from pulp mill sludge using wet oxidation and thermal hydrolysis. Bioresour. Technol. 2013, 146, 294-300. [CrossRef]

5. Ratia, H.; Rämänen, H.; Lensu, A.; Oikari, A. Betulinol and wood sterols in sediments contaminated by pulp and paper mill effluents: Dissolution and spatial distribution. Environ. Sci. Pollut. Res. 2013, 20, 4562-4573. [CrossRef] [PubMed]

6. Vidal, G.; Becerra, J.; Hernández, V.; Decap, J.; Xavier, C.R. Anaerobic biodegradation of sterols contained in kraft mill effluents. J. Biosci. Bioeng. 2007, 104, 476-480. [CrossRef]

7. Kamali, M.; Khodaparast, Z. Review on recent developments on pulp and paper mill wastewater treatment. Ecotoxicol. Environ. Saf. 2015, 114, 326-342. [CrossRef]

8. Kaur, D.; Bhardwaj, N.K.; Lohchab, R.K. Environmental aspect of using chlorine dioxide to improve effluent and pulp quality during wheat straw bleaching. Waste Biomass. Valoriz. 2019, 10, 1231-1239. [CrossRef]

9. Tripathi, S.K.; Bhardwaj, N.K.; Roy-Ghatak, H. Developments in ozone-based bleaching of pulps. Ozone Sci. Eng. 2020, 42, 194-210. [CrossRef]

10. Bajpai, P. Green Chemistry and Sustainability in Pulp and Paper Industry, 1st ed.; Springer International Publishing: Cham, Switzerland, 2015.

11. Vidal, G.; Soto, M.; Méndez-Pampín, R.; Field, J.; Lema, J.M. Anaerobic biodegradability and toxicity of wastewaters from chlorine and total chlorine free bleaching of eucalyptus kraft pulps. Water Res. 1997, 31, 2487-2494. [CrossRef]

12. Nie, S.; Yao, S.; Wang, S.; Qin, C. Absorbable organic halide (AOX) reduction in elemental chlorine-free (ECF) bleaching of bagasse pulp from the addition of sodium sulphide. BioResources 2016, 11, 713-723. [CrossRef]

13. Hinck, M.L.; Ferguson, J.; Puhaakka, J. Resistance of EDTA and DTPA to aerobic biodegradation. Water Sci. Technol. 1997, 35, 25-31. [CrossRef] 
14. Pinto, I.S.; Neto, I.F.; Soares, H.M. Biodegradable chelating agents for industrial, domestic, and agricultural applications-A review. Environ. Sci. Pollut. Res. 2014, 21, 11893-11906. [CrossRef] [PubMed]

15. Vidal, G.; Videla, S.; Diez, M.C. Molecular weight distribution of Pinus radiata kraft mill wastewater treated by anaerobic digestion. Bioresour. Technol. 2001, 77, 183-191. [CrossRef]

16. Milestone, C.B.; Fulthorpe, R.R.; Stuthridge, T.R. The formation of colour during biological treatment of pulp and paper wastewater. Water Sci. Technol. 2004, 50, 87-94. [CrossRef] [PubMed]

17. Ko, J.J.; Shimizu, Y.; Ikeda, K.; Kim, S.K.; Park, C.H.; Matsui, S. Biodegradation of high molecular weight lignin under sulfate reducing conditions: Lignin degradability and degradation by-products. Bioresour. Technol. 2009, 100, 1622-1627. [CrossRef]

18. Vidal, G.; Navia, R.; Levet, L.; Mora, M.L.; Diez, M.C. Kraft mill anaerobic effluent color enhancement by a fixed-bed adsorption system. Biotechnol. Lett. 2001, 23, 861-865. [CrossRef]

19. Lindholm-Lehto, P.C.; Knuutinen, J.S.; Ahkola, H.S.; Herve, S.H. Refractory organic pollutants and toxicity in pulp and paper mill wastewaters. Environ. Sci. Pollut. Res. 2015, 22, 6473-6499. [CrossRef]

20. Kamaya, Y.; Tokita, N.; Suzuki, K. Effects of dehydroabietic acid and abietic acid on survival, reproduction, and growth of the crustacean Daphnia magna. Ecotoxicol. Environ. Saf. 2005, 61, 83-88. [CrossRef]

21. Peng, G.; Roberts, J. Solubility and toxicity of resin acid. Water Res. 2000, 34, 2779-2785. [CrossRef]

22. Belmonte, M.; Xavier, C.; Decap, J.; Martínez, M.; Sierra, R.; Vidal, G. Improvement of the abietic acid biodegradation contained in ECF effluent due to biomass adaptation. J. Hazard. Mat. 2006, 135, 256-263. [CrossRef] [PubMed]

23. Cook, D.L.; LaFleur, L.; Parrish, A.; Jones, J.; Hoy, D. Characterization of plant sterols from 22 US pulp and paper mills. Water Sci. Technol. 1997, 35, 297-303. [CrossRef]

24. Güçlü-Üstündag, Ö.; Temelli, F. Correlating the solubility behavior of minor lipid components in supercritical carbon dioxide. J. Supercrit. Fluids 2004, 31, 235-253. [CrossRef]

25. MacLatchy, D.; Peters, L.; Nickle, J.; Van der Kraak, G. Exposure to $\beta$-sitosterol alters the endocrine status of glodfish differently than 17ß-estradiol. Environ. Toxicol. Chem. 1997, 16, 1895-1904. [CrossRef]

26. Mahmood-Khan, Z.M.; Hall, E.R. Occurrence and removal of plant sterols in pulp and paper mill effluents. J. Environ. Eng. Sci. 2003, 2, 17-26. [CrossRef]

27. Kiparissis, Y.; Hudhes, R.; Metcalfe, C.; Ternes, T. Identification of the isoflavonoid genistein in bleached kraft mill effluent. Environ. Sci. Technol. 2003, 35, 2423-2427. [CrossRef]

28. Monsálvez, E.; Jarpa, M.; Xavier, C.; Vidal, G. Evaluation of conventional biological treatment technologies to remove estrogenic potential from cellulose effluents. Water Technol. 2009, 29, 54-62. (In Spanish)

29. Orrego, R.; Hewitt, L.M.; McMaster, M.; Chiang, G.; Quiroz, M.; Munkittrick, K.; Gavilán, J.; Barra, R. Assessing wild fish exposure to ligands for sex steroid receptors from pulp and paper mill effluents in the Biobio River Basin, Central Chile. Ecotoxicol. Environ. Saf. 2019, 171, 256-263. [CrossRef]

30. Chamorro, S.; Monsalvez, E.; Piña, B.; Olivares, A.; Hernández, V.; Becerra, J.; Vidal, G. Analysis of aryl hydrocarbon receptor ligands in kraft mill effluents by a combination of yeast bioassays and CG-MS chemical determinations. J. Environ. Sci. Health Part A 2013, 48, 145-151. [CrossRef] [PubMed]

31. Chiang, G.; Barra, R.; Diaz-Jaramillo, M.; Rivas, M.; Bahamonde, P.; Munkittrick, K.R. Estrogenicity and intersex in juvenile rainbow trout (Oncorhynchus mykiss) exposed to Pine/Eucalyptus pulp and paper production effluent in Chile. Aquat. Toxicol. 2015, 164, 126-134. [CrossRef] [PubMed]

32. Xavier, C.; Chamorro, S.; Vidal, G. Chronic effects of Kraft mill effluents and endocrine active chemical on Daphnia magna. Bull. Environ. Contam. Toxicol. 2005, 75, 670-676. [CrossRef] [PubMed]

33. Campos, B.; Piña, B.; Fernández-Sanjuán, M.; Lacorte, S.; Barata, C. Enhanced offspring production in Daphnia magna clones exposed to serotonin reuptake inhibitors and 4-nonylphenol. Stage and food-dependent effects. Aquat. Toxicol. 2012, 109, 100-110. [CrossRef] [PubMed]

34. Lopes, A.C.; Mounteer, A.H.; Stoppa, T.V.; Aquino, D.S. Biological activity of bleached kraft pulp mill effluents before and after activated sludge and ozone treatments. Water Sci. Technol. 2013, 67, 333-339. [CrossRef] [PubMed]

35. Céspedes, R.; Lacorte, S.; Raldúa, D.; Ginebreda, A.; Barceló, D.; Piña, B. Distribution of endocrine disruptors in the Llobregat River basin (Catalonia, NE Spain). Chemosphere 2005, 61, 1710-1719. [CrossRef] [PubMed]

36. Vorrink, S.U.; Domann, F.E. Regulatory crosstalk and interference between the xenobiotic and hypoxia sensing pathways at the AhR-ARNT-HIF1 $\alpha$ signaling node. Chem. Biol. Interact. 2014, 218, 82-88. [CrossRef] [PubMed]

37. Bovee, T.; Bor, G.; Heskamp, H.; Hoogenboom, R.; Nielen, M. Validation and application of a robust yeast estrogen bioassay for the screening of estrogenic activity in animal feed. Food Addit. Contam. 2006, 23, 556-568. [CrossRef]

38. Peltier, W.; Weber, C. Methods for Measuring the Acute Toxicity of Effluents to Freshwater and Marine Organisms; Environmental Protection Agency: Washington, DC, USA, 2002.

39. Kim, H.J.; Koedrith, P.; Seo, Y.R. Ecotoxicogenomic approaches for understanding molecular mechanisms of environmental chemical toxicity using aquatic invertebrate, Daphnia model organism. Int. J. Mol. Sci. 2015, 16, 12261-12287. [CrossRef]

40. Olmstead, A.W.; LeBlanc, G.A. Effects of endocrine-active chemicals on the development of sex characteristics of Daphnia magna. Environ. Toxicol. Chem. 2000, 19, 2107-2113. [CrossRef] 
41. Oakes, K.D.; Tremblay, L.A.; van der Kraak, G.J. Short-term lab exposures of immature rainbow trout (Oncorhynchus mykiss) to sulfite and kraft pulp-mill effluents: Effects on oxidative stress and circulating sex steroids. Environ. Toxicol. Chem. 2005, 24, 1451-1461. [CrossRef]

42. Van den Heuvel, M.R.; Landman, M.J.; Tremblay, L.A. Responses of shortfin eel (Anguilla australis) exposed in situ to pulp and paper effluent. J. Environ. Sci. Health Part A 2006, 69, 1763-1779. [CrossRef] [PubMed]

43. West, D.W.; Ling, N.; Hicks, B.J.; Tremblay, L.A.; Kim, N.D.; van Den Heuvel, M.R. Cumulative impacts assessment along a large river, using brown bullhead catfish (Ameiurus nebulosus) populations. Environ. Toxicol. Chem. 2006, 25, 1868-1880. [CrossRef]

44. Machala, M.; Vondráček, J.; Bláha, L.; Ciganek, M.; Neča, J. Aryl hydrocarbon receptor-mediated activity of mutagenic polycyclic aromatic hydrocarbons determined using in vitro reporter gene assay. Mutat. Res. 2001, 497, 49-62. [CrossRef]

45. Lavado, R.; Urena, R.; Martin-Skilton, R.; Torreblanca, A.; Del Ramo, J.; Raldua, D.; Porte, C. The combined use of chemical and biochemical markers to assess water quality along the Ebro River. Environ. Pollut. 2006, 139, 330-339. [CrossRef] [PubMed]

46. Piña, B.; Casado, M.; Quiros, L. Analysis of gene expression as a new tool in ecotoxicology and environmental monitoring. TrAC Trends. Anal. Chem. 2007, 26, 1145-1154. [CrossRef]

47. Quirós, L.; Jarque, S.; Lackner, R.; Fernández, P.; Grimalt, J.O.; Piña, B. Physiological response to persistent organic pollutants in fish from mountain lakes: Analysis of Cyp1A gene expression in natural populations of Salmo trutta. Environ. Sci. Technol. 2007, 41, 5154-5160. [CrossRef] [PubMed]

48. Eljarrat, E.; Martínez, M.Á.; Sanz, P.; Concejero, M.A.; Piña, B.; Quirós, L.; Raldúa, D.; Barceló, D. Distribution and biological impact of dioxin-like compounds in risk zones along the Ebro River basin (Spain). Chemosphere 2008, 71, 1156-1161. [CrossRef] [PubMed]

49. Shimizu, Y.; Nakatsuru, Y.; Ichinose, M.; Takahashi, Y.; Kume, H.; Mimura, J.; Fujii-Kuriyama, Y.; Ishikawa, T. Benzo [a] pyrene carcinogenicity is lost in mice lacking the aryl hydrocarbon receptor. Proc. Natl. Acad. Sci. USA 2000, 97, 779-782. [CrossRef]

50. Abel, J.; Haarmann-Stemmann, T. An introduction to the molecular basics of aryl hydrocarbon receptor biology. Biol. Chem. 2010, 391, 1235-1248. [CrossRef]

51. Cody, R.P.; Bortone, S.A. Masculinization of Mosquitofish as an indicator of exposure to kraft mill effluent. Bull. Environ. Contam. Toxicol. 1997, 58, 429-436. [CrossRef]

52. Mellanen, P.; Soimasuo, M.; Holbom, B.; Oikari, A.; Santti, R. Expression of the vitellogenin gene in the liver of juvenile whitefish (Coregonus lavaretus L. sl.) exposed to effluents from pulp and mills. Ecotoxicol. Environ. Saf. 1999, 43, 133-137. [CrossRef]

53. Diniz, M.S.; Peres, I.; Magalhaes-Antoine, I.; Falla, J.; Pihan, J.C. Estrogenic effects in crucian carp (Carassius carassius) exposed to treated sewage effluent. Ecotoxicol. Environ. Saf. 2005, 62, 427-435. [CrossRef]

54. Christianson-Heiska, I.; Haavisto, T.; Paranko, J.; Bergelin, E.; Isomaa, B. Effects of the wood extractives dehydroabietic acid and betulinol on reproductive physiology of zebrafish (Danio rerio)—A two-generation study. Aquat. Toxicol. 2008, 86, 388-396. [CrossRef]

55. Nagao, T.; Yoshimura, S.; Saito, Y.; Nakagomi, M.; Usumi, K.; Ono, H. Reproductive effects in male and female rats of neonatal exposure to genistein. Reprod. Toxicol. 2001, 15, 399-411. [CrossRef]

56. Kim Oanh, N.T.; Bengtsson, B.-E. Toxicity to Microtox, micro-algae and duckweed of effluents from the Bai Bang paper company (BAPACO), a Vietnamese bleached kraft pulp and paper mill. Environ. Poll. 1995, 90, 391-399. [CrossRef]

57. Chamorro, S.; Pozo, G.; Jarpa, M.; Hernández, V.; Becerra, J.; Vidal, G. Monitoring endocrine activity in kraft mill effluent treated by Aerobic moving bed bioreactor system. Water Sci. Technol. 2010, 62, 157-161. [CrossRef] [PubMed]

58. Fernández, M.; Ikonomu, M.; Buchanan, I. An assessment of strogenic organic contaminants in Canadian wastewater. Sci. Total Environ. 2007, 373, 250-269. [CrossRef] [PubMed]

59. Xavier, C.R. Influence of Treatment Technology on the Biodegradation of Phytosterols Contained in Kraft Mill Effluents and on the Toxicity of These Compounds in Aquatic Organisms. Doctoral Thesis, Universidad de Concepción, Concepción, Chile, 2006; p. 140.

60. Pozo, G. Removal Optimization of Nutrients in Biological Reactors of Immobilized Bacterial Biofilm: Incidence in the Biosynthesis of Polyhydroxyalkanoate (PHA) as a Product of the Treatment of Kraft mill effluents. Master's Thesis, University of Concepción, Concepción, Chile, 2010; p. 130.

61. Jarpa, M. Secondary and Tertiary Treatment of Effluents from the Forestry Industry and Their Effect on Toxicity. Doctoral Thesis, Universidad de Concepción, Concepción, Chile, 2014; p. 203.

62. Chamorro, S.; Xavier, C.R.; Vidal, G. Behaviour of aromatic compounds contained in kraft mill effluents treated by an aerated lagoon. Biotechnol. Prog. 2005, 21, 1567-1571. [CrossRef] [PubMed]

63. da Mata, R.A.; Morais, I.L.H.; Silva, C.M. Characterization of thermophilic aerobic granular sludge for the treatment of bleached kraft pulp mill effluent. Bioresources 2020, 15, 7191-7206. [CrossRef]

64. Kostamo, A.; Holmbom, B.; Kukkonen, J.V.K. Fate of wood extractives in wastewater treatment plants at kraft pulp mills and mechanical pulp mills. Water Res. 2004, 38, 972-982. [CrossRef] [PubMed]

65. Eskelinen, K.; Särkkä, H.; Agustiono, T.; Sillanpää, M. Removal of recalcitrant contaminants from bleaching effluents in pulp and paper mills using ultrasonic irradiation and Fenton-like oxidation electrochemical treatment and/or chemical precipitation: A comparative study. Desalination 2010, 255, 179-187. [CrossRef]

66. Chaparro, T.R.; Botta, C.M.; Pires, E.C. Toxicity and recalcitrant compound removal from bleaching pulp plant effluents by an integrated system: Anaerobic packed-bed bioreactor and ozone. Water Sci. Technol. 2010, 61, 199-205. [CrossRef] 
67. Stephenson, R.; Duff, S. Coagulation and precipitation of a mechanical pulping effluent-I Removal of carbon, colour and turbidity. Water Res. 1996, 30, 781-792. [CrossRef]

68. Stephenson, R.; Duff, S. Coagulation and precipitation of a mechanical pulping effluent-II Toxicity removal and metal salt recovery. Water Res. 1996, 30, 793-798. [CrossRef]

69. Catalkaya, E.C.; Kargi, F. Color, TOC and AOX removals from pulp mill effluent by advanced oxidation processes: A comparative study. J. Hazard. Mater. 2007, 139, 244-253. [CrossRef]

70. Espuglas, S.; Bila, D.; Krause, L.; Dezzoti, M. Ozonization and advanced oxidation technologies disrupting chemicals (EDCs) and pharmaceuticals and personal care products (PPCPs) in water effluents. J. Hazard. Mater. 2007, 149, 631-642.

71. Torrades, F.; Montserrat, P.; Mansilla, H.; Peral, J. Experimental design of Fenton and Photo-Fenton reactions for the treatment of cellulose bleaching effluents. Chemosphere 2003, 53, 1211-1220. [CrossRef]

72. Fontanier, V.; Farines, V.; Albert, J.; Baig, S.; Molinier, J. Study of catalyzed ozonation for advanced treatment of pulp and paper mill effluents. Water Res. 2006, 40, 303-310. [CrossRef] [PubMed]

73. Ledakowics, S.; Michniewicz, M.; Jagiella, A.; Stufka-Olczyk, J.; Martynelis, M. Elimination of resin acids by advanced oxidation processes and their impact on subsequent biodegradation. Water Res. 2006, 40, 3439-3446. [CrossRef]

74. Pérez, M.; Torrades, F.; Garcia-Hortal, J.; Doménech, X.; Peral, J. Removal of organic contaminants in paper pulp treatment effluents under Fenton and photo-Fenton conditions. Appl. Catal. B Environ. 2002, 36, 63-74. [CrossRef]

75. Mansilla, H.; Yeber, M.; Freer, J.; Rodríguez, J.; Baeza, J. Homogeneous and heterogeneous advanced oxidation of a bleaching effluent from the pulp and paper industry. Water Sci. Technol. 1997, 35, 273-278. [CrossRef]

76. Kansal, S.; Singh, M.; Sud, D. Effluent quality at Kraft/soda agro-based paper mills and its treatment using a heterogeneous photocatalytic system. Desalination 2008, 228, 183-190. [CrossRef]

77. Catalkaya, E.; Kargi, F. Advanced oxidation treatment of pulp mill effluent for TOC and toxicity removals. J. Environ. Manag. 2008, 87, 396-404. [CrossRef] [PubMed]

78. Dube, M.; McLean, R.; MacLatchy, D.; Savage, P. Reverse osmosis treatment: Effects on effluent quality final effluent quality improves. Pulp Pap. Can. 2000, 101, 42-45.

79. Rosa, M.J.; de Pinho, M.N. The role of ultrafiltration and nanofiltration on the minimization of the environmental impact of bleached pulp effluents. J. Membr. Sci. 1995, 102, 155-161. [CrossRef]

80. Salvaterra, A.F.; Sarmentoa, G.; Minhalma, M.; de Pinhoa, M.N. Nanofiltration of surface water for the removal of endocrine disruptors. Desalin. Water Treat. 2011, 35, 54-61. [CrossRef]

81. Lazarova, V.; Liechti, P.A.; Savoye, P.; Hausler, R. Ozone disinfection: Main parameters for process design in wastewater treatment and reuse. J. Water Reuse Desalin. 2014, 3, 337-345. [CrossRef]

82. Mainardis, M.; Buttazzoni, M.; De Bortoli, N.; Mion, M.; Goi, D. Evaluation of ozonation applicability to pulp and paper streams for a sustainable wastewater treatment. J. Clean. Prod. 2020, 258, 120781. [CrossRef]

83. Yeber, M.C.; Soto, C.; Riveros, R.; Navarrete, J.; Vidal, G. Optimization by factorial design of copper (II) and toxicity removal using a photocatalytic process with $\mathrm{TiO}_{2}$ as semiconductor. Chem. Eng. J. 2009, 152, 14-19. [CrossRef]

84. Rajput, H.; Changotra, R.; Sangal, V.K.; Dhir, A. Photoelectrocatalytic treatment of recalcitrant compounds and bleach stage pulp and paper mill effluent using $\mathrm{Au}-\mathrm{TiO}_{2}$ nanotube electrode. Chem. Eng. J. 2020, 408, 127287. [CrossRef]

85. Bajpai, P. (Ed.) Purification of process water in closed-cycle mills. In Biermann's Handbook of Pulp and Paper, 3rd ed.; Elsevier: Amsterdam, The Netherlands, 2018; pp. 527-546.

86. Yaqub, M.; Lee, W. Zero-liquid discharge (ZLD) technology for resource recovery from wastewater: A review. Sci. Total Environ. 2019, 681, 551-563. [CrossRef]

87. Lee, H.J.; Hong, M.K.; Han, S.D.; Cho, S.H.; Moon, S.H. Fouling of an anion exchange membrane in the electrodialysis desalination process in the presence of organic foulants. Desalination 2009, 238, 60-69. [CrossRef]

88. Balakshin, M.Y.; Capanema, E.A.; Sulaeva, I.; Schlee, P.; Huang, Z.; Feng, M.; Borghei, M.; Rojas, O.J.; Potthast, A.; Rosenau, T. New opportunities in the valorization of technical lignins. ChemSusChem 2021, 14, 1016-1036. [CrossRef] [PubMed]

89. Fendrihan, S.; Pop, C.E. Biotechnological potential of plant associated microorganisms. Rom. Biotechnol. Lett. 2021, 26, 22700-22706. [CrossRef]

90. Lynd, L.R.; Wyman, C.E.; Gerngross, T.U. Biocommodity Engineering. Biotechnol. Prog. 1999, 15, 777-793. [CrossRef] [PubMed] 